\title{
From $\mathrm{Cu}_{2} \mathrm{~S}$ nanocrystals to $\mathrm{Cu}$ doped $\mathrm{CdS}$ nanocrystals through cation exchange: controlled synthesis, optical properties and their p-type conductivity research
}

\author{
Jian Liu ${ }^{1}$, Yuheng Zhao ${ }^{1}$, Jialong $\mathrm{Liu}^{2}$, Shouguo Wang ${ }^{3}$, Yan Cheng ${ }^{4}$, Muwei $^{1}{ }^{1}$, Yuanmin Zhou ${ }^{1}$, \\ Meng $\mathrm{Xu}^{1}$, Weichang $\mathrm{Hao}^{2}$ and Jiatao Zhang ${ }^{1^{*}}$
}

Heterovalent doping represents an effective method to control the optical and electronic properties of semiconductor nanocrystals (NCs), such as the luminescence and electronic impurities (p-, n-type doping). Considering the phase structure diversity, coordination varieties of $\mathrm{Cu}$ atoms in $\mathrm{Cu}_{2} \mathrm{~S} \mathrm{NCs}$, and complexity of $\mathrm{Cu}$ doping in II-VI NCs, monodisperse $\mathrm{Cu}_{2} \mathrm{~S}$ NCs with pure hexagonal phase were synthesized firstly. Then through cation exchange reaction between $\mathrm{Cd}$ ions and well-defined $\mathrm{Cu}_{2} \mathrm{~S}$ NCs, dominant $\mathrm{Cu}(\mathrm{I})$ doped $\mathrm{CdS}$ NCs were produced successfully. The substitutional $\mathrm{Cu}(\mathrm{I})$ dopants with controllable concentrations were confirmed by local atom-specific fine structure from $\mathrm{X}$-ray absorption near edge structure (XANES), extended X-ray absorption fine structure (EXAFS) spectroscopy, elemental analysis characterizations from $\mathrm{X}$-ray photoelectron spectroscopy (XPS) and the electron spin resonance (ESR) measurement. The dominant and strong $\mathrm{Cu}(\mathrm{I})$ dopant fluorescence was verified by their absorption and photoluminescence (PL) spectra, and PL lifetime. Finally, the band positions and the p-type conductivities of the as-prepared $\mathrm{Cu}_{2} \mathrm{~S}$ and $\mathrm{Cu}(\mathrm{I})$ doped $\mathrm{CdS}$ NCs were identified by ultraviolet photoelectron spectroscopy (UPS) measurements. The high monodispersity of NCs enables their strong film-scale self-assembly and will hasten their subsequent applications in devices.

\section{INTRODUCTION}

Doping transition metal ions into II-VI semiconductor nanocrystals (NCs), by the intentional insertion of impurities, such as $\mathrm{Mn}, \mathrm{Cu}$ and $\mathrm{Ag}$ ions, has garnered enormous interests in the past two decades. They have exhibited the advantages such as tunable emission, large Stoke shifts, thermal stability, and higher excited state lifetime [1-6].
Along this direction, $\mathrm{Cu}(\mathrm{I})$ and $\mathrm{Ag}(\mathrm{I})$ ions could act as heterovalent dopants and control both optical and electronic impurities properties of II-VI NCs [6-11]. However, the common problem to be encountered in the case of $\mathrm{Cu}$ doped semiconductor NCs is the oxidation state of $\mathrm{Cu}$ ions and induced stable p-type conductivity $[12,13]$. Evidence from several reports showed that both $\mathrm{Cu}(\mathrm{I})$ and $\mathrm{Cu}(\mathrm{II})$ ions were stable in the oxidation state, which results in the difficulty in defining the $\mathrm{Cu}$ doping locations and establishing the mechanism of $\mathrm{Cu}$ luminescence [10-15]. For instance, some reports verified that sulfide could reduce $\mathrm{Cu}(\mathrm{II})$ to $\mathrm{Cu}(\mathrm{I})$ ions by electron paramagnetic resonance (EPR) measurement in $\mathrm{CdS}$ and $\mathrm{ZnS}$ hosts, which establish that $\mathrm{Cu}(\mathrm{I})$ can be the stable oxidation state $[11,14]$. Therefore, in order to get substitutional $\mathrm{Cu}(\mathrm{I})$ doping in II-VI NCs with higher purity, we chose stoichiometric $\mathrm{Cu}_{2} \mathrm{~S}$ NCs as starting materials and took advantage of cation exchange between them and $\mathrm{Cd}^{2+}$ ions to get $\mathrm{Cu}(\mathrm{I})$ doped CdS NCs.

Copper sulfide includes many solid phases known as $\mathrm{CuS}, \mathrm{Cu}_{1.8} \mathrm{~S}, \mathrm{Cu}_{1.96} \mathrm{~S}$ and $\mathrm{Cu}_{2} \mathrm{~S}$, because of the common coexistence of $\mathrm{Cu}(\mathrm{II})$ and $\mathrm{Cu}(\mathrm{I})$ ions [16,17]. They have been identified as p-type semiconductor materials, because of copper vacancies in their crystal lattice [18]. The synthesis of their monodisperse NCs with high pure phase is necessary for their further optical, electronic applications. However, $\mathrm{Cu}_{2} \mathrm{~S}$ NCs are prone to form mixed phases as previous reports, which limit their electronic applications $[17,19]$. $\mathrm{CdS}$ is an important II-VI semiconductor material with bulk band gap of $2.4 \mathrm{eV}$. Due to the self-compensation ef-

\footnotetext{
${ }^{1}$ Beijing Key Laboratory of Construction-Tailorable Advanced Functional Materials and Green Applications, School of Materials Science \& Engineering, Beijing Institute of Technology, Beijing 100081, China

${ }^{2}$ Department of Physics, Beihang University, Beijing 100191, China

${ }^{3}$ Department of Materials Physics and Chemistry, University of Science and Technology Beijing, Beijing 100083, China

${ }^{4}$ Laboratory of Chemical Biology, Changchun Institute of Applied Chemistry, Chinese Academy of Sciences, Changchun 130022, China

* Corresponding author (email: zhangjt@bit.edu.cn)
} 
fect from intrinsic $S$ vacancies that serve as donor dopants, CdS exists as n-type semiconductor naturally [20,21]. It is difficult to synthesize CdS NCs with p-type doping. However, with the advantages in band alignment and cathodic protection, p-type CdS can overcome the shortcomings of n-type CdS in photocathodes [22].

Due to intrinsic self-purification effect of dopants [1], in order to get stable p-type or n-type doped level in semiconductor NCs, the acquirement of effective heterovalent substitutional doping is the very first step. Cation exchange has been demonstrated as a synthetic strategy to obtain monodisperse semiconductor NCs with preserving original size, shape and tunable composition and dopants of semiconductor NCs [23-27]. Several research groups have achieved the electronic impurities through the cation exchange between II-VI NCs matrix and dopant ions [4,28,29]. In order to get deep-position location of $\mathrm{Cu}(\mathrm{I})$ dopants in $\mathrm{CdS}$ matrix, we took a special cation exchange process (Fig. 1a) between $\mathrm{Cu}^{+}$ions in stoichiometric $\mathrm{Cu}_{2} \mathrm{~S} \mathrm{NCs}$ and $\mathrm{Cd}^{2+}$ in solution. From exterior to interior, trace tributylphosphine (TBP) initiates cation exchange and generates single crystalline $\mathrm{CdS}$ NCs with trace $\mathrm{Cu}(\mathrm{I})$ residue deep inside. Therefore, we synthesized monodisperse stoichiometric $\mathrm{Cu}_{2} \mathrm{~S}$ NCs with pure hexagonal phase firstly. Then through cation exchange reactions of Fig. 1a, dominant $\mathrm{Cu}(\mathrm{I})$ doping in $\mathrm{CdS}$ NCs was obtained. The $\mathrm{Cu}(\mathrm{I})$ doping with controllable concentrations in produced CdS NCs lattice matrix and dominantly substitution of $\mathrm{Cd}$ ions were confirmed by $\mathrm{X}$-ray photoelectron spectroscopy (XPS), X-ray absorption near edge structure (XANES) analysis and the electron spin resonance (ESR) measurement. Cu(I) dopant induced stable luminescence was demostrated by the room-temperature steady photoluminescence (PL) spectra and luminescence lifetime. The p-type conductivities and band structures of the as-prepared $\mathrm{Cu}_{2} \mathrm{~S}$ and $\mathrm{Cu}(\mathrm{I})$ doped $\mathrm{CdS}$ NCs were identified by ultraviolet photoelectron spectroscopy (UPS) analysis.

\section{EXPERIMENTAL SECTION}

\section{Materials}

All chemicals were used without further processing. Copric chloride dihydrate $\left(\mathrm{CuCl}_{2} \cdot 2 \mathrm{H}_{2} \mathrm{O}, \# 10125-13-0,>99 \%\right.$ purity) and sodium stearate $\left(\mathrm{C}_{18} \mathrm{H}_{35} \mathrm{NaO}_{2}\right.$, \#822-16-2, $>96 \%$ purity) were purchased from Beijing Chemical Works. Dodecanethiol (DDT, \#122-55-0, >98\% purity) was purchased from Sinopharm Chemical Reagent Co., Ltd. TBP(\#998-40-3, >95\% purity) and cadmium nitrate tetrahydrate $\left(\mathrm{Cd}\left(\mathrm{NO}_{3}\right)_{2} \cdot 4 \mathrm{H}_{2} \mathrm{O}\right.$, \#10022-68-1, >99\% purity) were purchased from Aladdin. Oleic acid $\left(\mathrm{C}_{18} \mathrm{H}_{34} \mathrm{O}_{2}, \# 112-80-1\right.$,
$>99 \%$ purity) were purchased from Aladdin and oleymanine $\left(\mathrm{C}_{18} \mathrm{H}_{37} \mathrm{~N}\right.$, \#112-90-3, 80\%-90\% purity) was purchased from Beijing InnoChem Science \& Technology Co., Ltd.

\section{Monodisperse $\mathrm{Cu}_{2} \mathrm{~S}$ NCs preparation}

The copper stearate $\left(\mathrm{Cu}(\mathrm{St})_{2}\right)$ was systhesized according to the reference [30]. Then, $0.25 \mathrm{mmol}(157.7 \mathrm{mg}) \mathrm{Cu}(\mathrm{St})_{2}$ and $0.25 \mathrm{~mL}$ DDT were mixed in a Teflon autoclave, followed by adding $5 \mathrm{~mL}$ oleic acid and $3 \mathrm{~mL}$ oleymanine. After stirring for $3 \mathrm{~min}$, the mixture was heated at $200^{\circ} \mathrm{C}$ for $2.5 \mathrm{~h}$. The resulting products were precipitated by ethanol and dispersed in toluene.

\section{$\mathrm{Cu}(\mathrm{I})$ doped $\mathrm{CdS}$ NCs preparation}

Typically, $0.25 \mathrm{mmol} \mathrm{Cu}_{2} \mathrm{~S}$ NCs dispersed in $8 \mathrm{~mL}$ toluene were mixed with $1 \mathrm{~mL} \mathrm{Cd}\left(\mathrm{NO}_{3}\right)_{2} \cdot 4 \mathrm{H}_{2} \mathrm{O}$ methanol solution $(0.1 \mathrm{~g} / \mathrm{mL})$. Then, $0.1 \mathrm{~mL}$ TBP was added, and the mixture was reacted at $56^{\circ} \mathrm{C}$ for $2 \mathrm{~h}$ under magnetic stirring. The resulting products were precipitated by ethanol and dispersed in toluene. $2.2 \%$ concentration of $\mathrm{Cu}$ dopants in $\mathrm{CdS}$ NCs can be obtained.

To achieve different concentrations of $\mathrm{Cu}$ dopants, the addition of $\mathrm{Cd}\left(\mathrm{NO}_{3}\right)_{2} \cdot 4 \mathrm{H}_{2} \mathrm{O}$ methanol solution and the reaction temperature should be altered. For $4 \%$ concentration of $\mathrm{Cu}$ dopants in $\mathrm{CdS}$ NCs, for instance, $0.1 \mathrm{~mL}$ $\mathrm{Cd}\left(\mathrm{NO}_{3}\right)_{2} \cdot 4 \mathrm{H}_{2} \mathrm{O}(0.1 \mathrm{~g} / \mathrm{mL})$ methanol solution should be added to the $\mathrm{Cu}_{2} \mathrm{~S}$ colloid solution and the reaction temperature should be changed from $56^{\circ} \mathrm{C}$ to $25^{\circ} \mathrm{C}$. Also, to get $0.5 \% \mathrm{Cu}$ dopants, $3 \mathrm{~mL} \mathrm{Cd}\left(\mathrm{NO}_{3}\right)_{2} \cdot 4 \mathrm{H}_{2} \mathrm{O}(0.1 \mathrm{~g} / \mathrm{mL})$ methanol solution was needed and the reaction temperature should be kept at $65-70^{\circ} \mathrm{C}$ for $3 \mathrm{~h}$. When $4 \mathrm{~mL}$ $\mathrm{Cd}\left(\mathrm{NO}_{3}\right)_{2} \cdot 4 \mathrm{H}_{2} \mathrm{O}(0.1 \mathrm{~g} / \mathrm{mL})$ methanol solution was added and kept at $65-70^{\circ} \mathrm{C}$ for $5 \mathrm{~h}$, similarly, the more compelete cation exchange would happen. In this case, the $\mathrm{Cu}$ dopant concentration was almost close to $0 \%$.

\section{Low resolution and high resolution transmission electron microscopy}

Samples for transmission electron microscopy (TEM) characterizations were prepared by placing one drop of toluene colloid onto a 300 mesh copper grid with a carbon support film. A JEOL JEM 1200EX working at $100 \mathrm{kV}$ and a high-resolution TEM (FEI Tecnai G2 F20 S-Twin working at $200 \mathrm{kV}$ ) were utilized to characterize the morphology, crystal lattice details, energy dispersive spectra (EDS) elemental mapping and line scan elemental analysis. The HRTEM image intensity was analyzed by DigitalMicrograph (Gatan Co. LTD.).

To investigate the location and extent of lattice distortion of the as-prepared CdS NCs induced by Cu doping, in- 


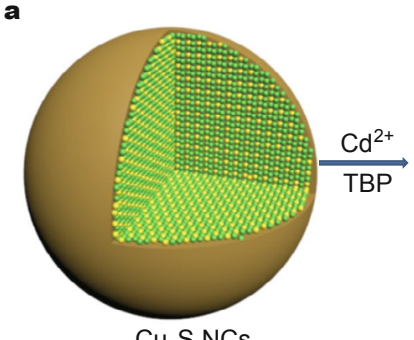

$\mathrm{Cu}_{2} \mathrm{~S} \mathrm{NCs}$
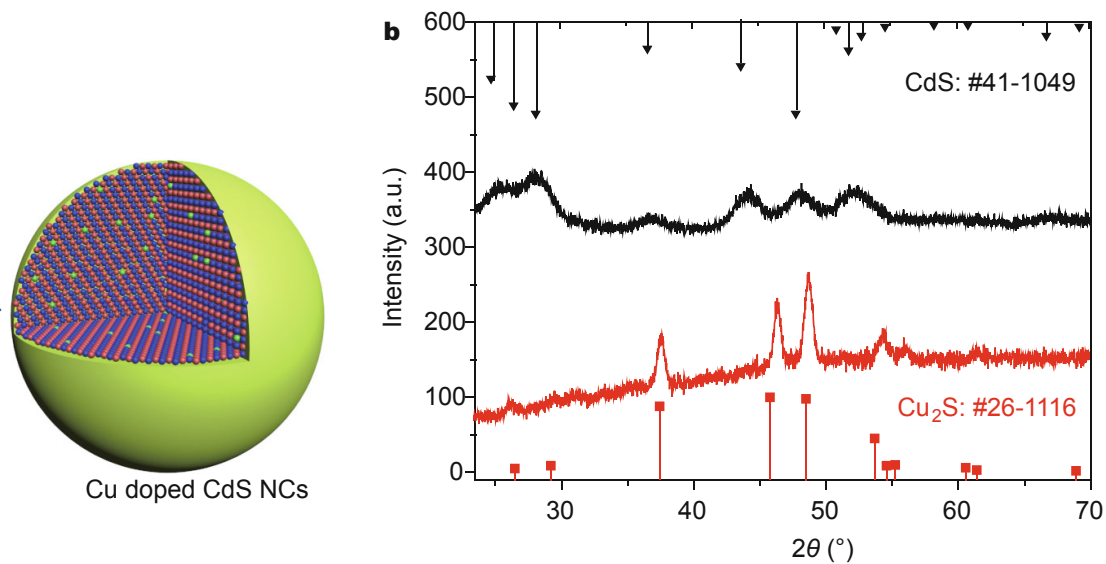

c

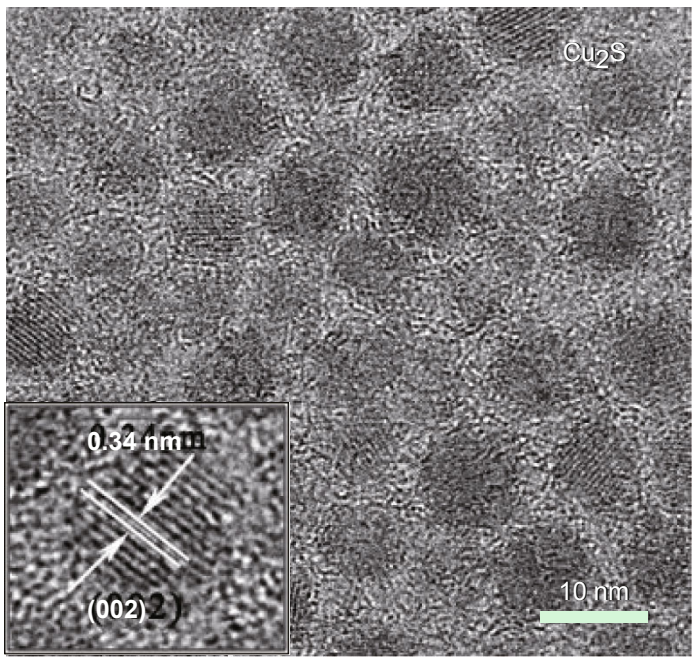

d
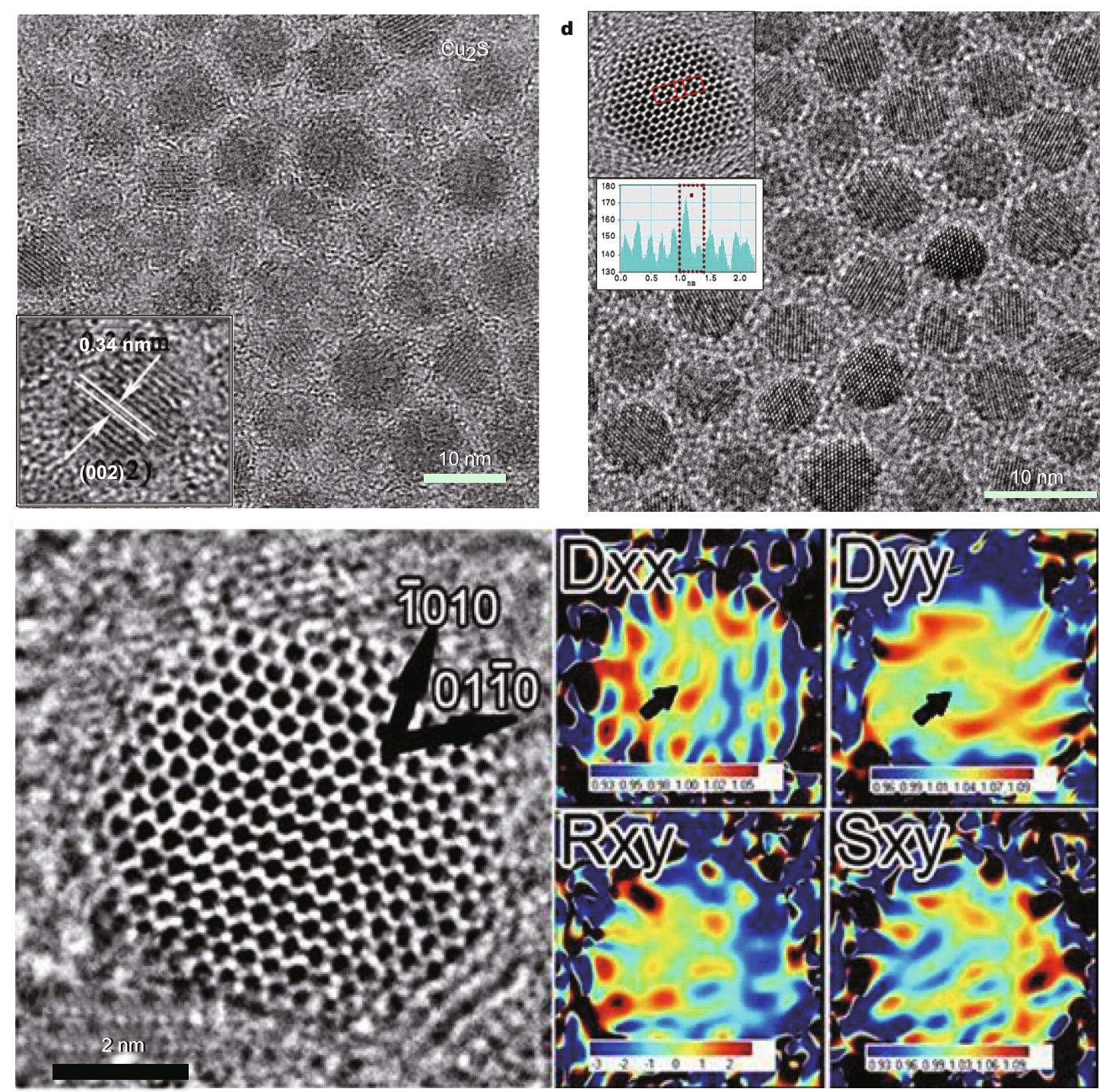

Figure 1 (a) Schematic illustration of the preparation process to achieve deep monovalent Cu doping in CdS NCs. (b) XRD patterns of the as-prepared $\mathrm{Cu}_{2} \mathrm{~S}$ and CdS NCs. (c and d) HRTEM images of $\mathrm{Cu}_{2} \mathrm{~S}$ NCs (c) and Cu doped CdS NCs (d), inset: single particle of CdS NCs and line profile analysis by digital micrograph. (e) Typical HRTEM image of Cu doped CdS NC along <0001> and corresponding strain mappings for Dxx, Dyy, Rxy and Sxy by GPA analysis. 
plane strain was calculated by STEM_CELL software based on the developed theory, geometric phase analysis (GPA), which enables us to construct false colour strain maps of fringe deformation in two reference directions (Dxx and $\mathrm{D} y y)$, fringe rotation $(\mathrm{R} x y)$ and shear strain $(\mathrm{S} x y)$.

\section{Inductive coupled plasma-optical emission spectroscopy analysis}

$100 \mathrm{mg} / \mathrm{mL} \mathrm{Cu}$ doped CdS NCs in hexane were evaporated to powders for the $\mathrm{Cu}$ dopants concentration analysis using inductive coupled plasma-optical emission spectroscopy (ICP-OES) from ICP-OES iCAP6300. The measurement parameters were: plasma power $1150 \mathrm{~W}$; atomozied gas velocity $0.6 \mathrm{~L} / \mathrm{min}$; auxiliary flow $0.5 \mathrm{~L} / \mathrm{min}$; pump rate $50 \mathrm{rpm}$.

\section{XPS analysis}

The XPS spectra were obtained from a PHI Quantera II $\mathrm{X}$-ray photoelectron spectrometer using $\mathrm{Al} \mathrm{Ka}$ non-monochromatic radiation. The colloidal nanocrystals were dip-coated on glass substrate for XPS characterization. The measurement parameters were: light spot size $100 \mu \mathrm{m}$; power $100 \mathrm{~W}$; voltage $20 \mathrm{kV}$. An energy correction was made to account for sample charging based on the $\mathrm{C} 1 \mathrm{~s}$ peak at $284.8 \mathrm{eV}$. The elemental concentrations were reported relative to carbon, calculated from the XPS spectra based on the area of the characteristic photoelectron peaks after correcting for atomic sensitivity.

\section{XANES and EXAFS characterizations}

The $\mathrm{Cd} k$-edge and $\mathrm{Cu} k$-edge XANES and EXAFS (extended X-ray absorption fine structure) spectra of CdS NCs doped with $\mathrm{Cu}$ were collected in fluorescence mode due to the lower concentration, and the $\mathrm{Cu} k$-edge of $\mathrm{CuS}$ and $\mathrm{Cu}_{2} \mathrm{~S}$ were collected in transmission mode on beamline BL14W1 at Shanghai Synchrotron Radiation Facility (SSRF), Shanghai Institute of Applied Physics (SINAP), China.The electron beam energy was $3.5 \mathrm{GeV}$, and the maximum stored current was $300 \mathrm{~mA}$. The raw data analysis was performed by using the FEFF6 software package according to the standard data analysis procedures.

\section{ESR measurement}

EPR measurements were performed with powder samples at room temperature in an electron spin resonance spectrometer (JEOL ESR FA-200) at X-band (9.0 GHz).

\section{UV-Vis-NIR absorption and photoluminescence spectroscopy}

The UV-Vis-NIR absorption spectra of the as prepared
CdS QDs toluene colloids were recorded on a Shimadzu UV3600 UV-Vis-NIR spectrophotometer at room temperature (RT). The steady state luminescence spectra of colloidal samples were collected on a Hitachi F-4500 fluorescence spectrophotometer at RT.

\section{Fluorescence lifetime characterization}

The $p s$ time-resolved fluorescence apparatus supplied with the excitation laser pulses $(450 \mathrm{~nm})$ by an optical parametric amplifier (OPA-800CF, Spectra Physics) was used and the measurements were carried out at RT. The excitation energy at the sample was $50 \mathrm{~nJ} /$ pulse. Fluorescence collected with the $90^{\circ}$-geometry was dispersed by a polychromator (250is, Chromex) and detected by a streak camera (C5680, Hamamatsu Photonics). Analysis of the kinetic traces derived from time-resolved spectra was performed individually using nonlinear least-squares fitting to a general sum-of-exponentials function after deconvolution of the instrument response function (IRF). The absolute quantum yields of $2.2 \% \mathrm{Cu}$ doped CdS NCs was analyzed on Hamamatsu absolute quantum yield spectrometer C11347 with the excitation laser pulses $(360 \mathrm{~nm})$.

\section{UPS characterizations}

Samples were analyzed on Thermo Scientific ESCALab 250Xi using UPS. The gas discharge lamp was used for UPS, with helium gas admitted and the He I (21.22 eV) emission line employed. The helium pressure in the analysis chamber during analysis was about $2 \times 10^{-8}$ mbar. The data were acquired with $-10 \mathrm{~V}$ bias.

\section{RESULTS AND DISCUSSION}

Many reports indicated that colloidal $\mathrm{Cu}_{2} \mathrm{~S}$ NCs were prone to form as the hexagonal and cubic phase mixtures [19,31]. Herein, hexagonal phase chalcocite $\mathrm{Cu}_{2} \mathrm{~S}$ NCs (JCPDS \# 26-1116) with good purity and crystallization were synthesized successfully, as confirmed by XRD pattern and the indexed lattice spacing in Figs $1 \mathrm{~b}$ and $\mathrm{c}$. Then based on cation exchange process shown in Fig. 1a, hexagonal structured CdS NCs (JCPDS \# 41-1049) were produced (see also XRD patterns in Fig. 1b). The cation exchange scheme in Fig. 1a hints the possiblity that little of $\mathrm{Cu}^{+}$remains in the NCs. The presence of $\mathrm{Cu}$ residue was confirmed by ICPOES elemental analysis and could reach to the concentration of $2.2 \%$ typically (Table S1 in the supplementary information). It is difficult to identify $\mathrm{Cu}$ atoms in $\mathrm{CdS}$ lattice matrix directly by TEM imaging because of the adjacent atomic numbers of $\mathrm{Cu}$ to $\mathrm{Cd}$. Herein, based on the correction with HRTEM image of CdS without defects (Fig. S1), line profile analysis by digital micrograph (Fig. 1d) and the 
strain mapping by GPA of HRTEM images were applied to characterize the $\mathrm{Cu}$ doping induced lattice strain. The inserted intensity line profiles along the rectangles in Fig. $1 \mathrm{~d}$ show intensity changes from the substitution by $\mathrm{Cu}^{+}$for $\mathrm{Cd}^{2+}$ in the lattice matrix. The binding force of S-Cd differs with that of $\mathrm{S}-\mathrm{Cu}$ in $\mathrm{Cu}$ doped $\mathrm{CdS}$ NCs, leading to lattice distortion and thus contrast variation pixel by pixel. From GPA analysis (see the details of GPA analysis in SI-1), it is indicated that $\mathrm{Cu}(\mathrm{I})$ ions are in the deep position of $\mathrm{CdS}$ matrix.

The large-scale TEM images in Figs $2 \mathrm{a}$ and $\mathrm{b}$ confirm the high monodispersity of as-prepared $\mathrm{Cu}_{2} \mathrm{~S}$ and $\mathrm{Cu}$ doped CdS NCs with the average diameter of $4.1 \mathrm{~nm}$. The high monodispersity of NCs and the appropriate van der Waal forces provided by the capping ligands enable the self-assembly of NCs into superlattice $[19,32]$. As a result, largescale multilayer superlattices of $\mathrm{Cu}_{2} \mathrm{~S}$ and $\mathrm{Cu}$ doped $\mathrm{CdS}$
NCs with hexagonal close packing order can be easily estabilished (Figs $2 \mathrm{c}$ and d). This effective bottom-up self-assembly has laid the foundation for their use in large-area film applications (see also the insert pictures of their films). When prolonging the reaction time of $\mathrm{Cu}_{2} \mathrm{~S}$ NCs to $3 \mathrm{~h}$, the average size of $\mathrm{Cu}_{2} \mathrm{~S}$ NCs could be tailored to be $5.9 \mathrm{~nm}$ and then similarly sized $\mathrm{Cu}$ doped CdS NCs could be obtained via cation exchange (see Fig. S2).

To characterize the $\mathrm{Cu}$ dopants concentration and locations via cation exchange, XPS, XANES and EXAFS spectroscopy of $\mathrm{Cu}$ doped CdS NCs were carried out. XPS analysis of the as-prepared CdS NCs are shown in Figs 3a, 3b and S3. The Cd $3 d$ peak is split into $3 d_{5 / 2}(403.5 \mathrm{eV})$ and $3 \mathrm{~d}_{3 / 2}(410.3 \mathrm{eV})$ peaks and the peaks at 160.5 and $161.5 \mathrm{eV}$ correspond to S 2p transitions (Fig. S3). These observed binding energy values are in agreement with the reported data on CdS NCs $[33,34]$. The Cu dopant XPS spectra
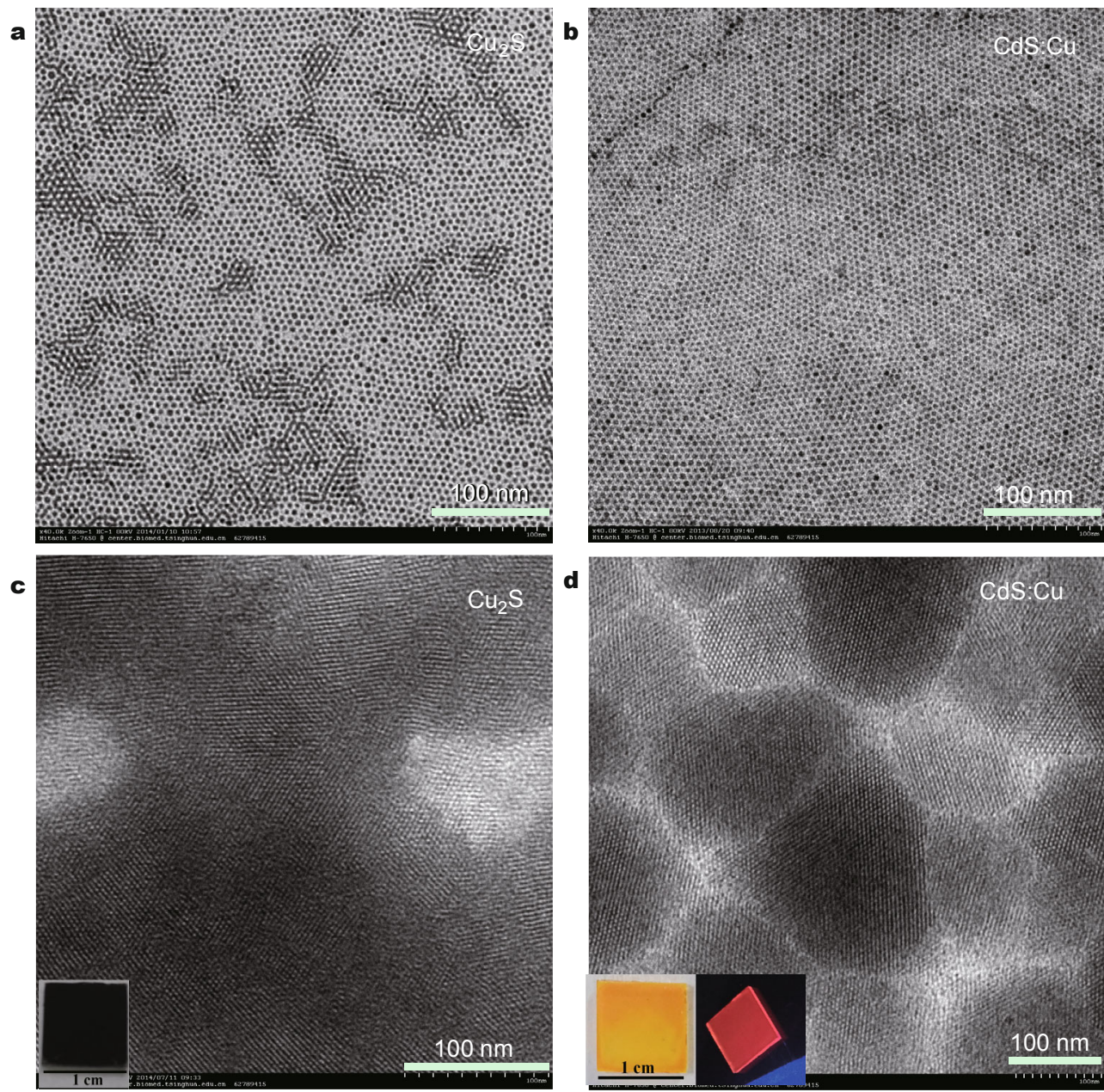

Figure 2 HRTEM images of (a) $\mathrm{Cu}_{2} \mathrm{~S}$ and (b) $\mathrm{Cu}$ doped CdS NCs. (c and d) NCs and their initiative large-scale self-assembly into superlattice, with the inset showing their bulk sized film on glass substrate. 

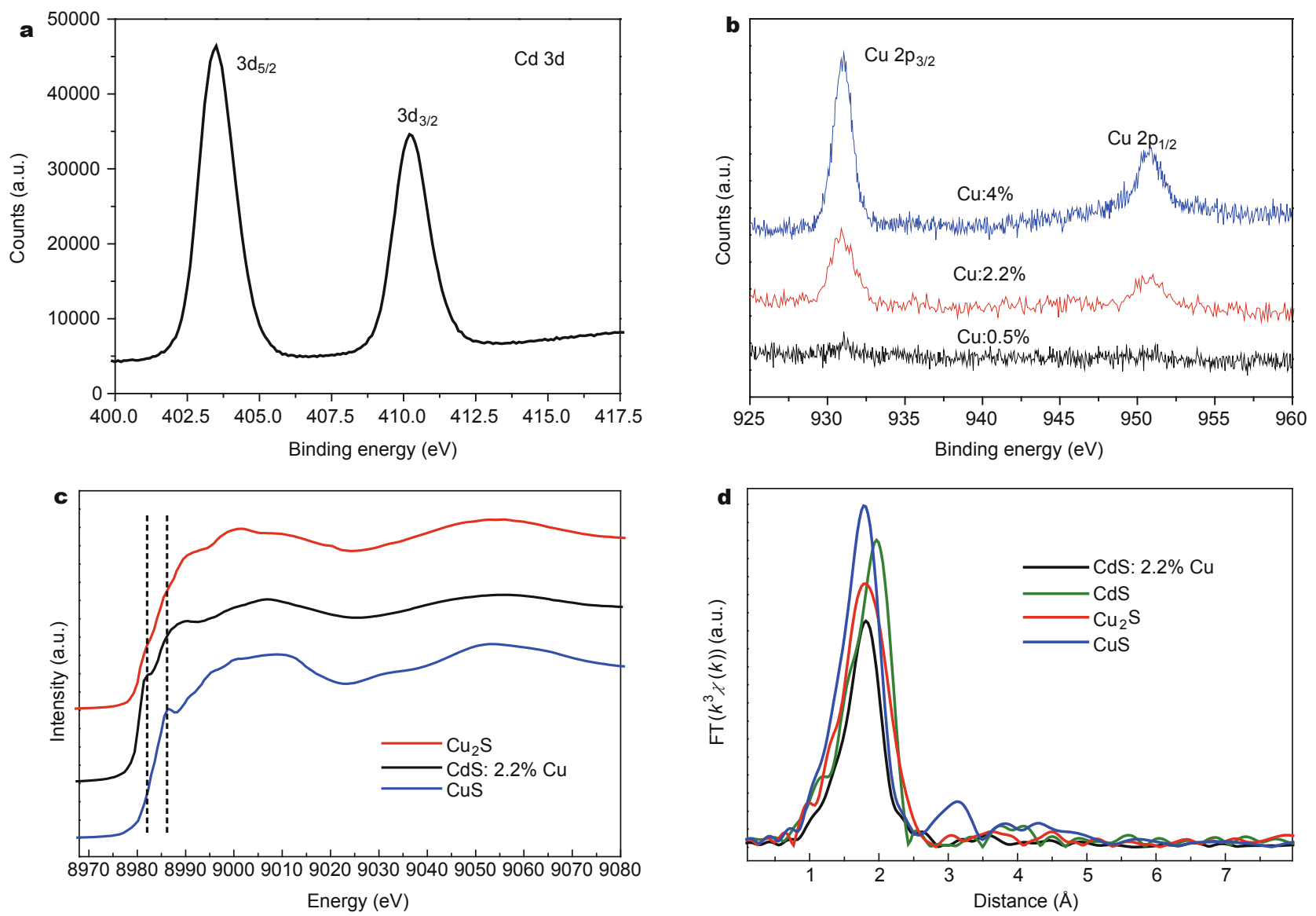

Figure 3 XPS spectra of $\mathrm{Cd} 3 \mathrm{~d}$ (a) and $\mathrm{Cu} 2 \mathrm{p}$ (b) in the as-prepared CdS NCs. (c) Cu $k$-edge XANES spectra of CuS, Cu $\mathrm{Cu}_{2}$, and $2.2 \% \mathrm{Cu}$ dopant in $\mathrm{CdS}$ NCs. (d) Magnitude of the Fourier transforms of $k^{3}$-weighted $\mathrm{Cu} k$-edge and $\mathrm{Cd} k$-edge EXAFS functions in $2.2 \% \mathrm{Cu}$ doped $\mathrm{CdS} \mathrm{NCs}$, $\mathrm{Cu} \mathrm{S}_{2} \mathrm{SCs}$, and $\mathrm{CuS}$.

with different concentrations $(4 \%, 2.2 \%$ and $0.5 \%)$ in Fig. 3b show two symmetric peaks at 931.8 and $951.5 \mathrm{eV}$ with a peak splitting of $19.8 \mathrm{eV}$, characteristic of monovalent copper [35]. XANES and EXAFS analysis are useful to determine the oxidation states of the $\mathrm{Cu}$ dopants and the nearest neighbor coordination profiles of $\mathrm{Cu}$ atoms [36-38]. The $k$-edge XANES spectra of $2.2 \% \mathrm{Cu}$ dopants is shown in Fig. 3c, compared with $\mathrm{CuS}$ and $\mathrm{Cu}_{2} \mathrm{~S}$. As shown, $\mathrm{Cu}(\mathrm{I})$ compound $\mathrm{Cu}_{2} \mathrm{~S}$ exhibits a lower energy absorption edge at about $8982 \mathrm{eV}$, while the $\mathrm{Cu}(\mathrm{II})$ compound $\mathrm{CuS}$ shows higher energy at $8985 \mathrm{eV}$, as indicated by the dash lines. The absorption edge of CdS: $2.2 \% \mathrm{Cu}$ (at $8982 \mathrm{eV}$ ) is more close to that of $\mathrm{Cu}_{2} \mathrm{~S}$, suggesting the valence of $\mathrm{Cu}$ in $\mathrm{CdS}$ : $2.2 \% \mathrm{Cu}$ is +1 dominantly. It is consistent with the XPS results. Fig. $3 \mathrm{~d}$ shows the $\mathrm{Cu} k$-edge Fourier transform of $k^{3}$-weighted functions without phase correction for $\mathrm{Cu}_{2} \mathrm{~S}$, $\mathrm{CuS}$, and $\mathrm{CdS}: 2.2 \% \mathrm{Cu}$. For comparison, Cd $k$-edge EXAFS spectrum for CdS is also presented. Compared with $\mathrm{Cu}_{2} \mathrm{~S}$ and $\mathrm{CuS}$, the coordination environment of $\mathrm{Cu}$ in $\mathrm{CdS}$ :
$2.2 \% \mathrm{Cu}$ is similar to that of $\mathrm{Cu}_{2} \mathrm{~S}$. It is because that there are two coordination peaks in $\mathrm{CuS}$ while only one in $\mathrm{Cu}_{2} \mathrm{~S}$ and CdS: $2.2 \% \mathrm{Cu}$. In addition, the bond length of $\mathrm{Cu}-\mathrm{S}$ in $\mathrm{CdS}: 2.2 \% \mathrm{Cu}$ is shorter than $\mathrm{Cd}-\mathrm{S}$ bond length in $\mathrm{CdS}$ due to the smaller ionic radius of $\mathrm{Cu}^{+}$than $\mathrm{Cd}^{2+}$. These features support the dominance of substitutional $\mathrm{Cu}^{+}$doping. Furthermore, the similar tetrahedral location of $\mathrm{Cu}$ in $\mathrm{Cu}_{2} \mathrm{~S}$ to that of $\mathrm{Cd}$ in the $\mathrm{CdS}$ matrix and the same hexagonal-close-packed matrix of sulfur atoms in chalcocite $\mathrm{Cu}_{2} \mathrm{~S}$ and $\mathrm{CdS}$ are the prerequisites for substitutional $\mathrm{Cu}^{+}$ doping. The analysis of $\mathrm{Cu}$ XPS spectra in $\mathrm{CdS}$ NCs verifies that the oxidation state of $\mathrm{Cu}$ dopant here is mainly $\mathrm{Cu}^{+}$. This is also consistent with the experimental fact that $\mathrm{Cu}_{2} \mathrm{~S}$ NCs precursor with good phase purity is chosen as a starting material in cation exchange process.

To further confirm $\mathrm{Cu}^{+}$doping, the ESR measurement was performed on the $\mathrm{Cu}$-doped CdS NCs with $2.2 \%$ concentrations of $\mathrm{Cu}$ and no optical excitation was observed. Since the electron configuration of $\mathrm{Cu}^{+}$is $3 \mathrm{~d}^{10}$, it should be 
diamagnetic. If $\mathrm{Cu}$ exists as $\mathrm{Cu}^{0}$ or $\mathrm{Cu}^{2+}$ in $\mathrm{CdS} \mathrm{NCs}$, it will give an obvious paramagnetic signal [11]. The results of ESR measurement are shown in Fig. S4 in Supplementary information. The data were normalized by the magnification and $\mathrm{Cu}$ mass amounts in doped $\mathrm{CdS}$ samples, $\mathrm{CuCl}_{2}$ and $\mathrm{Cu}\left(\mathrm{NO}_{3}\right)_{2}$ which were calculated as $2 \%, 47.4 \%, 34 \%$, respectively. It clearly shows that ESR spectra from $\mathrm{CuCl}_{2}$ (red circles) and $\mathrm{Cu}\left(\mathrm{NO}_{3}\right)_{2}$ (blue diamonds) as reference samples exhibit strong signals with magnetic fields from 250 to $350 \mathrm{mT}$. This paramagnetic behavior comes from $\mathrm{d}^{9}$ electron configuration of $\mathrm{Cu}^{2+}$ in $\mathrm{CuCl}_{2}$ and $\mathrm{Cu}\left(\mathrm{NO}_{3}\right)_{2}$ respectively. However, no obvious paramagnetic signals are observed in this region of magnetic fields for $\mathrm{Cu}$ doped CdS samples, indicating that the samples are diamagnetic. The ESR measurements confirm the $\mathrm{Cu}^{+}$in $\mathrm{Cu}$ doped $\mathrm{CdS}$ samples, in good agreement with the analysis of XPS and XANES.

Fig. 4a shows the UV-Vis-NIR absorption spectrum of the as-synthesized $\mathrm{Cu}_{2} \mathrm{~S}$ NCs toluene colloid. Different from the nonstoichiometric $\mathrm{Cu}_{2-x} \mathrm{~S} \mathrm{NCs}$, there are no localized surface plasmon resonance (LSPR) induced absorp- tion peaks in NIR region [17]. The absorption spectrum in Fig. $4 \mathrm{a}$ only shows the $\mathrm{Cu}_{2} \mathrm{~S}$ band gap induced absorption edge feature. This stoichiometric composition of $\mathrm{Cu}_{2} \mathrm{~S}$ precursor is helpful to get dominant $\mathrm{Cu}(\mathrm{I})$ substitutional doping in CdS NCs after cation exchange. UV-Vis absorption and RT steady PL spectra of the as-prepared CdS NCs colloid with different $\mathrm{Cu}$ dopant concentrations are shown in Figs $4 \mathrm{~b}$ and $\mathrm{c}$. The quantum confinement induced exciton absorption features in Fig. $4 \mathrm{~b}$ confirm the CdS nanocrystal formation. Interestingly, exciton recombination induced emission in PL spectra can hardly be observed. However, with optimal $\mathrm{Cu}$ dopant concentration $(2.2 \%)$, the defect-related red fluorescence peak at about $620 \mathrm{~nm}$ is strong and dominant at room temperature. The absolute quantum yields of $2.2 \% \mathrm{Cu}$ doped $\mathrm{CdS}$ NCs reached to $28.9 \%$. The higher and lower concentrations of $\mathrm{Cu}$ doping (see $4 \%$ and $0.5 \% \mathrm{Cu}$ doping in Figs $4 \mathrm{~b}$ and c) both lead to weaker dopant PL because they are not good for stable dopant level formation. Consistent with the reported complete cation exchange by Alivisatos group [23], the $0 \% \mathrm{Cu}$ doping in CdS NCs here would lead to the coexistence of exciton re-
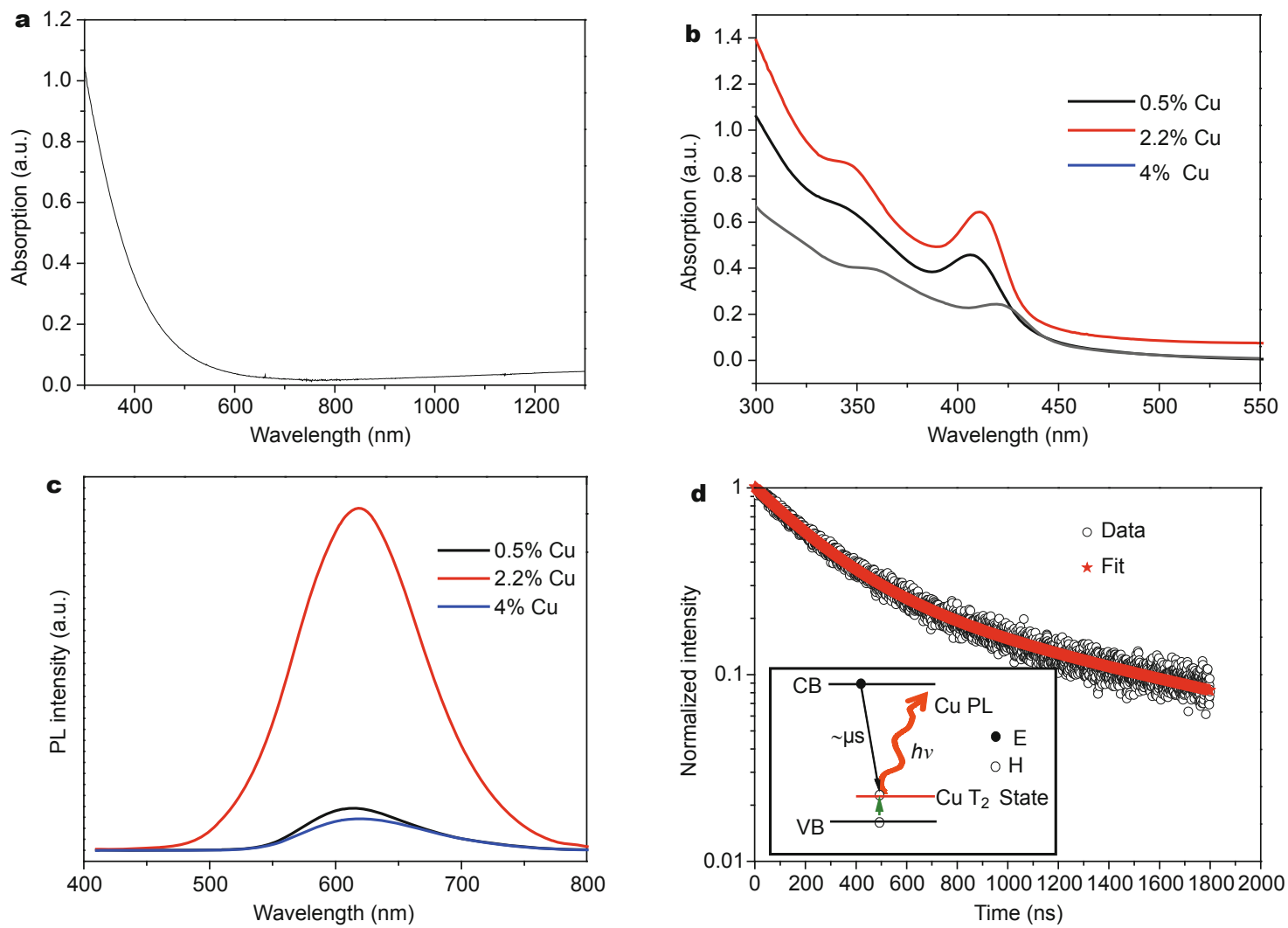

Figure 4 (a) UV-Vis-NIR absorption spectra of $\mathrm{Cu}_{2} \mathrm{~S}$ NCs. (b) Cu doped CdS NCs: UV-Vis absorption spectra with different Cu dopant concentrations. (c) Cu doped CdS NCs: RT steady state fluorescence spectra with different Cu dopant concentrations $\left(\lambda_{\mathrm{ex}}=400 \mathrm{~nm}\right)$. (d) Dopant emission dynamics monitored at the peaks of $620 \mathrm{~nm}$ by time-resolved fluorescence lifetime $(\tau)$ measurements, inset: schematic diagram of electronic structure responsible for dominant $2.2 \% \mathrm{Cu}$ dopant PL. 
combination induced emission and wide weak surface trap emission at $\sim 600 \mathrm{~nm}$ (see Fig. S5). As shown in Fig. 4d, the dominant fluorescence peak at $\sim 620 \mathrm{~nm}$ exhibits ultra-long lifetime decay behavior. The 620 -nm kinetic curve can be well fitted with a two-exponential model, resulting in two lifetimes of $0.2 \mu$ s and $1.3 \mu \mathrm{s}$, respectively. This long-lived fluorescence further supports the dominance of $\mathrm{Cu}$ dopant related emission. It is confirmed that this peak is not due to the surface states but because of the weak spatial overlap between the conduction band electron wave function and the localized copper state [39]. Though the nature of the $\mathrm{Cu}$-related center in the CdS is not fully understood, it is generally agreed that the center is related to $\mathrm{Cu} \mathrm{T}_{2}$ state [40], which results from the split of $\mathrm{Cu} d$ levels and stay above the valence band. One possible origin for this only dopant-related peak is the recombination of carriers that are bound to the impurity with those that are optically excited into the lowest quantum-confined level [7]. When $\mathrm{Cu}$ is in the +1 state, activation of the impurity band occurs via nonradiactive capture of a hole from the valence band, thus the $\mathrm{Cu}$ dopant emission results from the recombination of electrons from the conduction band and $\mathrm{Cu}$-bound holes in the $\mathrm{Cu} \mathrm{T}_{2}$ states [12]. The schematic diagram of electronic structure responsible for dominant $\mathrm{Cu}$ dopant $\mathrm{PL}$ is summarized in the insert schematic diagram in Fig. 4d. As a result, the self-quenching problem is solved here due to the large Stokes shift of $0.88 \mathrm{eV}$ (Fig. S6), with benefits for their potential applications in luminescent solar concentrators (LSCs) and bio-imaging [41,42].

UPS is a convincible way to determine the valence band and Fermi level positions of semiconductors [43,44]. The energy band diagrams of the as-prepared $\mathrm{Cu}_{2} \mathrm{~S}$ and $\mathrm{Cu}$ doped CdS NC films were determined by UPS and UVVis absorption measurements (Figs 5 and 6). Calculated from UPS analysis (Figs $5 \mathrm{a}$ and $\mathrm{b}$ ), the work function of the as-prepared $\mathrm{Cu}_{2} \mathrm{~S} \mathrm{NCs}$ is $4.67 \mathrm{eV}$ and the valence band maximum is $4.93 \mathrm{eV}$ (detailed calculations can be found in supplementary information SI-2). Based on the valence band maximum and the band gap of the $\mathrm{Cu}_{2} \mathrm{~S}$ NCs film (1.08 $\mathrm{eV}$ ) determined by UV-Vis absorption spectrum (Fig. $5 \mathrm{c}$ ), the schematic representation of calculated band level positions of $\mathrm{Cu}_{2} \mathrm{~S}$ NCs film can be obtained in Fig. 5d. Similar
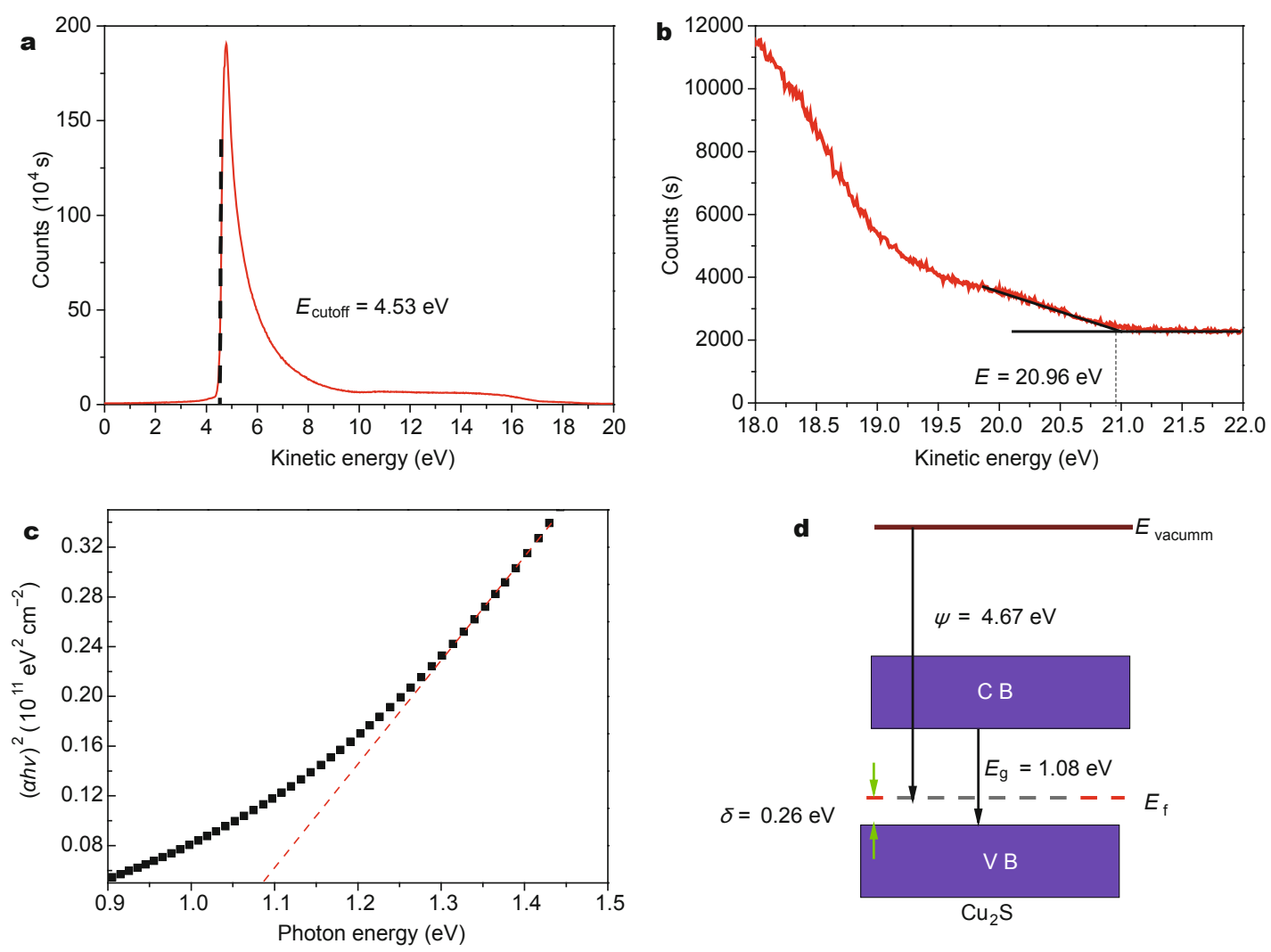

Figure 5 (a and b) UPS spectra of $\mathrm{Cu}_{2} \mathrm{~S} \mathrm{NC}$ film; (c) UV-Vis absorption spectrum for the $\mathrm{Cu}_{2} \mathrm{~S}$ NC film. (d) Energy band diagrams of Cu $\mathrm{S}_{2} \mathrm{SC}$ film determined from UPS and UV-Vis absorption measurements demonstrating calculation of work function and schematic representation of calculated band level positions. 

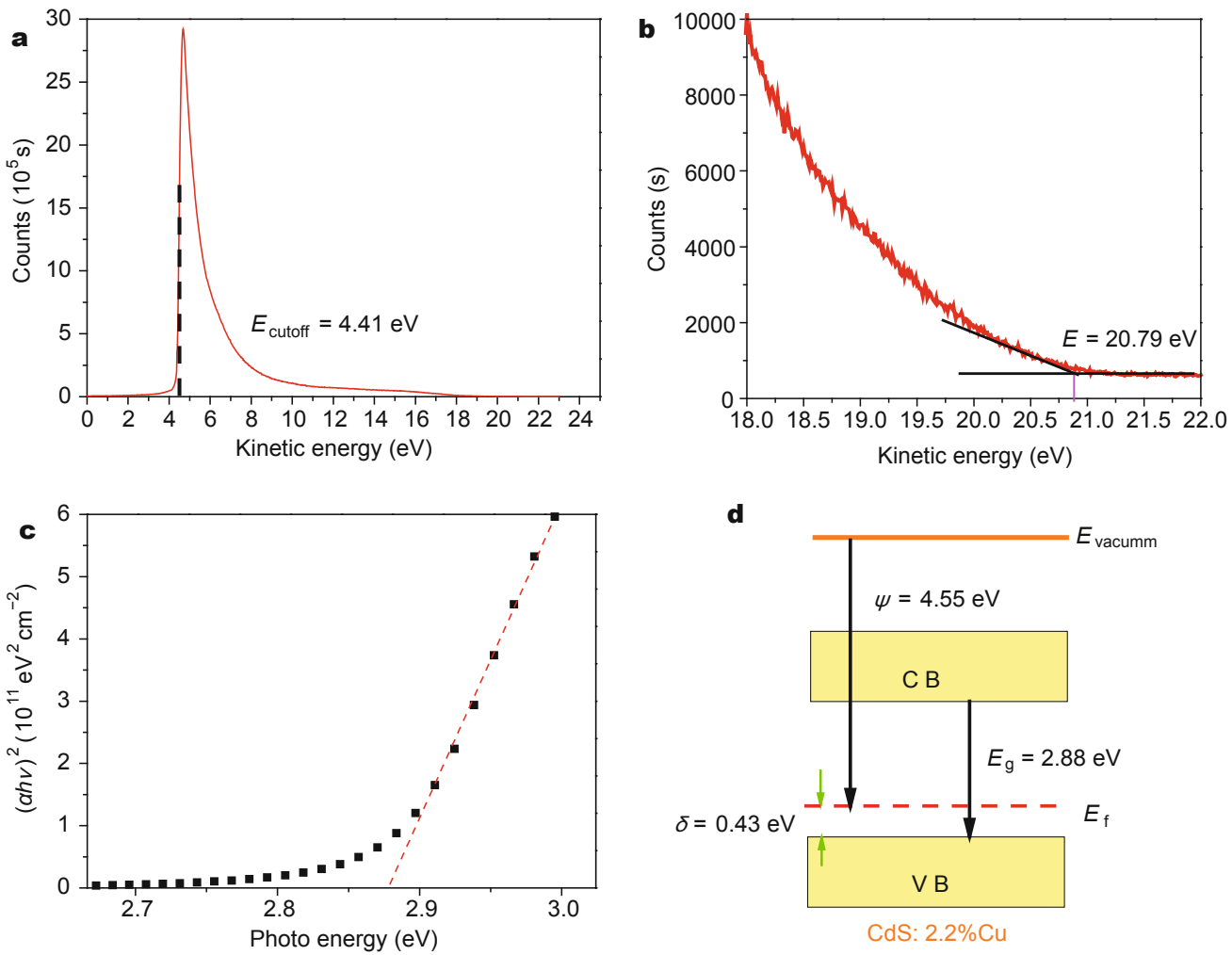

Figure 6 (a and b) UPS spectra of 2.2\% Cu doped CdS NCs film; (c) UV-Vis absorption spectrum for $2.2 \%$ Cu doped CdS NCs film. (d) Energy band diagrams of 2.2\% $\mathrm{Cu}$ doped CdS NCs film determined from UPS and UV-Vis absorption measurements demonstrating calculation of work function and schematic representation of calculated band level positions.

to the calculations of $\mathrm{Cu}_{2} \mathrm{~S}$ NCs film, $\mathrm{Cu}$ doped CdS NCs can also be figured out. Obviously, both the Fermi levels of $\mathrm{Cu}_{2} \mathrm{~S}$ film and $\mathrm{Cu}$ doped $\mathrm{CdS}$ film are closer to the valence band, which confirms that $\mathrm{Cu}_{2} \mathrm{~S}$ is a p-type semiconductor material and verifies that heterovalent $\mathrm{Cu}(\mathrm{I})$ impurities in CdS NCs can produce p-type electronic impurity. Consistent with the reported p-type CdS films created by ion-implantation of $\mathrm{Cu}$ acceptors [21], a large proportion of the $\mathrm{Cu}$ dopants here have substituted into $\mathrm{Cd}$ sites and acted as acceptors. They are compensated with electrons from Vs centers and accommodated on $\mathrm{Cd}$ sites as $\mathrm{Cu}^{+}$ions. This is the origin of the p-type conduction in CdS NCs.

\section{CONCLUSION}

In summary, the hexagonal phase $\mathrm{Cu}_{2} \mathrm{~S}$ NCs and their topotactic conversion to be $\mathrm{Cu}(\mathrm{I})$ doped CdS NCs by cation exchange were synthesized successfully. The dominant substitutional $\mathrm{Cu}(\mathrm{I})$ dopant leads to the effective dopant luminescence and p-type conductivity in CdS NCs. The UPS characterizations figured out their band structures and the p-type conductivity. This study will enhance the understanding about fundamental mechanism of $\mathrm{Cu}$ do- pants. The bottom-up assembly to be large-scale films will find wider potential applications in devices.

Received 22 August 2015; accepted 6 September 2015; published online 14 September 2015

1 Erwin SC, Zu LJ, Haftel MI, et al. Doping semiconductor nanocrystals. Nature, 2005, 436: 91-94

2 Norris DJ, Efros AL, Erwin SC. Doped nanocrystals. Science, 2008, 319: 1776-1779

3 Beaulac R, Schneider L, Archer PI, Bacher G, Gamelin DR Light-induced spontaneous magnetization in doped colloidal quantum dots. Science, 2009, 325: 973-976

4 Mocatta D, Cohen G, Schattner J, et al. Heavily doped semiconductor nanocrystal quantum dots. Science, 2011, 332: 77-81

5 Viswanatha R, Battaglia DM, Curtis ME, et al. Shape control of doped semiconductor nanocrystals (d-Dots). Nano Res, 2008, 1: 138-144

6 Viswanatha R, Brovelli S, Pandey A, Crooker SA, Klimov VI. Copper-doped inverted core/shell nanocrystals with "permanent" optically active holes. Nano Lett, 2011, 11: 4753-4758

7 Sahu A, Kang MS, Kompch A, et al. Electronic impurity doping in CdSe nanocrystals. Nano Lett, 2012, 12: 2587-2594

8 Jana S, Srivastava BB, Acharya S, et al. Prevention of photooxidation in blue-green emitting $\mathrm{Cu}$ doped $\mathrm{ZnSe}$ nanocrystals. Chem Commun, 2010, 46: 2853-2855

9 Xie Y, Carbone L, Nobile C, et al. Metallic-like stoichiometric 
copper sulfide nanocrystals: phase- and shape-selective synthesis, near-infrared surface plasmon resonance properties, and their modeling. ACS Nano, 2013, 7: 7352-7369

10 Bekenstein Y, Vinokurov K, Keren-Zur S, et al. Thermal doping by vacancy formation in copper sulfide nanocrystal arrays. Nano Lett, 2014, 14: 1349-1353

11 Cooper JK, Gul S, Lindley SA, Yano J, Zhang JZ. Tunable photoluminescent core/shell $\mathrm{Cu}^{+}$-doped $\mathrm{ZnSe} / \mathrm{ZnS}$ quantum dots codoped with $\mathrm{Al}^{3+}, \mathrm{Ga}^{3+}$, or $\mathrm{In}^{3+}$. ACS Appl Mater Interfaces, 2015, 7: 10055-10066

12 Brovelli S, Galland C, Viswanatha R, Klimov VI. Tuning radiative recombination in $\mathrm{Cu}$-doped nanocrystals via electrochemical control of surface trapping. Nano Lett, 2012, 12: 4372-4379

13 Srivastava BB, Jana S, Pradhan N. Doping $\mathrm{Cu}$ in semiconductor nanocrystals: some old and some new physical insights. J Am Chem Soc, 2011, 133: 1007-1015

14 Isarov AV, Chrysochoos J. Optical and photochemical properties of nonstoichiometric cadmium sulfide nanoparticles: surface modification with copper(II) ions. Langmuir, 1997, 13: 3142-3149

15 Sambasivam S, Sathyaseelan B, Raja Reddy D, Reddy BK, Jayasankar CK. ESR and photoluminescence properties of $\mathrm{Cu}$ doped $\mathrm{ZnS}$ nanoparticles. Spectrochim Acta Part A, 2008, 71A: 1503-1506

16 Zheng HM, Rivest JB, Miller TA, et al. Observation of transient structural-transformation dynamics in a $\mathrm{Cu}_{2} \mathrm{~S}$ nanorod. Science, 2011, 333: 207-209

17 Leidinger P, Popescu R, Gerthsen D, Lunsdorf H, Feldmann C. Nanoscale copper sulfide hollow spheres with phase-engineered composition: covellite $(\mathrm{CuS})$, digenite $\left(\mathrm{Cu}_{1.8} \mathrm{~S}\right)$, chalcocite $\left(\mathrm{Cu}_{2} \mathrm{~S}\right)$. Nanoscale, 2011, 3: 2544-2551

18 Riha SC, Jin S, Baryshev SV, et al. Stabilizing $\mathrm{Cu}_{2} \mathrm{~S}$ for photovoltaics one atomic layer at a time. ACS Appl Mater Interfaces, 2013, 5: 10302-10309

19 Zhuang ZB, Peng Q, Zhang BC, Li YD. Controllable synthesis of $\mathrm{Cu}_{2} \mathrm{~S}$ nanocrystals and their assembly into a superlattice. J Am Chem Soc, 2008, 130: 10482-10483

20 Desnica UV. Doping limits in II-VI compounds-challenges, problems and solutions. Prog Cryst Growth Charact Mater, 1998, 36: 291-357

21 Kashiwaba Y, Kanno I, Ikeda T. p-type characteristics of Cudoped CdS thin films. Jpn J Appl Phys, 1992, 31: 1170-1175

22 Huang Q, Li Q, Xiao XD. Hydrogen evolution from Pt nanoparticles covered p-type CdS:Cu photocathode in scavenger-free electrolyte. J Phys Chem C, 2014, 118: 2306-2311

23 Son DH, Hughes SM, Yin Y, Alivisatos AP. Cation exchange reactions-in ionic nanocrystals. Science, 2004, 306, 1009-1012

24 Gui J, Ji MW, Liu JJ, Xu M, Zhang JT. Phosphine-initiated cation exchange for precisely tailoring composition and properties of semiconductor nanostructures: old concept, new applications. Angew Chem Int Ed, 2015, 127, 3754-3758

25 Qian HM, Zhao Q, Dai BS, et al. Oriented attachment of nanoparticles to form micrometer-sized nanosheets/nanobelts by topotactic reaction on rigid/flexible substrates with improved electronic properties. NPG Asia Mater, 2015, 7: e152

26 Deng ML, Wang LY. Unexpected luminescence enhancement of upconverting nanocrystals by cation exchange with well retained small particle size. Nano Res, 2014, 7: 782-793

27 Beberwyck BJ, Surendranath Y, Alivisatos AP. Cation exchange: a versatile tool for nanomaterials synthesis. J Phys Chem C, 2013, 117: 19759-19770

28 Kang MS, Sahu A, Frisbie CD, Norris DJ. Influence of silver doping on electron transport in thin films of PbSe nanocrystals. Adv Mater, 2013, 25: 725-731

29 Liu J, Zhao Q, Liu JL, et al. Heterovalent-doping-enabled efficient dopant luminescence and controllable electronic impurity via a new strategy of preparing II-VI nanocrystals. Adv Mater, 2015, 27: 2753-2761

30 Li S, Wang HZ, Xu WW, et al. Synthesis and assembly of monodisperse spherical $\mathrm{Cu}_{2} \mathrm{~S}$ nanocrystals. J Colloid Interface Sci, 2009, 330: $483-487$

31 Rivest JB, Fong LK, Jain PK, Toney MF, Alivisatos AP. Size dependence of a temperature-induced-solid phase transition in copper(I) sulfide. J Phys Chem Lett, 2011, 2: 2402

32 Wang PP, Yang Y, Zhuang J, Wang X. Self-adjustable crystalline inorganic nanocoils. J Am Chem Soc, 2013, 135: 6834-6837

33 Zhu Y, Li Z, Chen M, et al. One-pot preparation of highly fluorescent cadmium telluride/cadmium sulfide quantum dots under neutral-pH condition for biological applications. J Colloid Interface Sci, 2013, 390: 3-10

34 Pan D, Wang Q, Pang J, et al. Semiconductor "nano-onions" with multifold alternating CdS/CdSe or CdSe/CdS structure. Chem Mater, 2006, 18: 4253-4258

35 Xuan T, Wang S, Wang X, et al. Single-step noninjection synthesis of highly luminescent water soluble $\mathrm{Cu}^{+}$doped $\mathrm{CdS}$ quantum dots: application as bio-imaging agents. Chem Commun, 2013, 49: 9045-9047

36 Rockenberger J, Trǒger L, Kornowski A, et al. EXAFS studies on the size dependence of structural and dynamic properties of CdS nanoparticles. J Phys Chem B, 1997, 101: 2691-2701

37 Gul S, Cooper JK, Glans P, et al. Effect of $\mathrm{Al}^{3+}$ co-doping on the dopant local structure, optical properties, and exciton dynamics in $\mathrm{Cu}^{+}$-doped ZnSe nanocrystals. ACS Nano, 2013, 7: 8680-8692

38 Sun ZH, Liu QH, Yao T, Yan WS, Wei SQ. X-ray absorption fine structure spectroscopy in nanomaterials. Sci China Mater, 2015, 58: 313-341

39 Grandhi GK, Viswanatha R. Tunable infrared phosphors using Cu doping in semiconductor nanocrystals: surface electronic structure evaluation. J Phys Chem Lett, 2013, 4: 409-415

40 Wang XB, Yan XS, Li WW, Sun K. Doped quantum dots for whitelight-emitting diodes without reabsorption of multiphase phosphors. Adv Mater, 2012, 24: 2742-2747

41 Meinardi F, Colombo A, Velizhanin KA, et al. Large-area luminescent solar concentrators based on 'stokes-shift-engineered' nanocrystals in a mass-polymerized PMMA matrix. Nat photonics, 2014, 8: 392-399

42 Krumer Z, Pera SJ, van Dijk-Moes RJA, et al. Tackling self-absorption in luminescent solar concentrators with type-II colloidal quantum dots. Sol Energ Mater Sol Cell, 2013, 111: 57-65

43 Chun WJ, Ishikawa $\mathrm{A}$, Fujisawa $\mathrm{H}$, et al. Conduction and valence band positions of $\mathrm{Ta}_{2} \mathrm{O}_{5}, \mathrm{TaON}$, and $\mathrm{Ta}_{3} \mathrm{~N}_{5}$ by UPS and electrochemical methods. J Phys Chem B, 2003, 107: 1798-1803

44 Cho KS, Lee EK, Joo WJ, et al. High-performance crosslinked colloidal quantum-dot light-emitting diodes. Nat Photonics, 2009, 3 : 341-345

Acknowledgements This work was supported by the National Natural Science Foundation of China (NSFC) (51372025, 21322105, 91323301, 51431009, and 51272015), the Research Fund for the Doctoral Program of Higher Education of China (2011101120016), the Program for New Century Excellent Talents in University (NCET-11-0793). We thank Mr. Yawei Hao and Prof. Haiyu Wang of the State Key Laboratory on Integrated Optoelectronics, College of Electronic Science and Engineering, Jilin University for luminescence lifetime measurements and helpful discussions. We thank Prof. Yang Sun of Institute of Physics, Chinese Academy of Sciences for the help on ESR measurements.

Author contributions Zhang $\mathrm{J}$ initiated and guided the whole project. 
Liu J, Zhao Y, Ji M, Zhou Y and Xu M conceived the study and wrote the manuscript. Liu $\mathrm{J}$ and Wang $\mathrm{S}$ executed the high resolution TEM study and ESR measurement. Cheng $\mathrm{Y}$ and Hao $\mathrm{W}$ acquired and analyzed the XANES spectra. All authors contributed to the discussion.
Conflict of interest The authors declare that they have no conflict of interest.

Supplementary information Experimental details and supporting data are available in the online version of the paper.

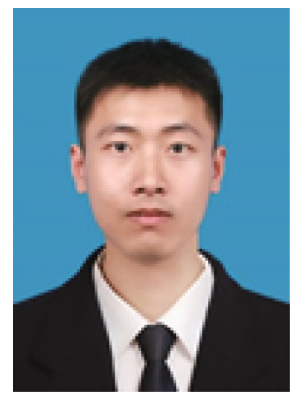

Jian Liu was born in Jiangsu, China, in 1991. He received his BSc degree in 2013 from the University of Shanghai for Science and Technology, and is now studying at Beijing institute of technology for his MSc degree. His research interest includes doping semiconductor nanocrystals.

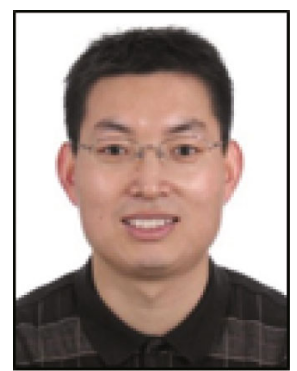

Jiatao Zhang was born in 1975. He received his PhD degree in 2006 from the Department of Chemistry, Tsinghua University, China. Currently he is Xu Teli Professor in the School of Materials and Engineering, Beijing Institute of Technology. He was awarded Excellent Young Scientist foundation of NSFC in 2013. He also serves as the director of Beijing Key Laboratory of Construction-Tailorable Advanced Functional Materials and Green Applications. His current research interest is inorganic chemistry of semiconductor based hybrid nanostructures to possess novel optical, electronic properties for applications in energy conversion and storage, catalysis, optoelectronics and biology.

中文摘要 异价掺杂, 能有效调控半导体纳米晶的电学及光学性能, 实现高效掺杂发光及 $\mathrm{n}$ 型、 $\mathrm{p}$ 型导电类型的调控. 因为 $\mathrm{Cu}_{2} \mathrm{~S}$ 晶型多 变、 $\mathrm{Cu}$ 原子配位繁杂以及 $\mathrm{Cu}$ 掺杂II-VI纳米晶的体系复杂等问题, 本文提出一种全新的方法, 首先可控制备了单分散的高纯度六方相 $\mathrm{Cu}_{2} \mathrm{~S}$ 纳米晶, 然后通过可控的离子交换反应, 合成了单分散 $\mathrm{Cu}(\mathrm{I})$ 掺杂的 $\mathrm{CdS}$ 纳米晶. 通过X射线近边吸收谱(XANES)、扩展X射线吸收 精细结构(EXAFS)、X射线光电子能谱(XPS)及电子顺磁共振波谱(EPR)等精确表征手段证实了可控浓度的取代型的异价 Cu掺杂. 其紫 外-可见吸收光谱、苂光光谱、苂光寿命光谱等表征证实了以 $\mathrm{Cu}(\mathrm{I})$ 掺杂为主导的掺杂发光, 绝对量子产率可达 $28.9 \%$. 紫外光电子能谱 $(\mathrm{UPS})$ 确认了 $\mathrm{Cu}(\mathrm{I})$ 掺杂的 $\mathrm{CdS}$ 为 $\mathrm{p}$ 型半导体. 高度单分散的 $\mathrm{CdS}$ 掺杂纳米晶可以形成大规模的自组装, 将会加速其在光电器件上的应用. 